\title{
Fataluku medicinal ethnobotany and the East Timorese military
} resistance

\author{
Sean WM Collins' ${ }^{1}$, Xisto Martins ${ }^{2}$, Andrew Mitchell ${ }^{3}$, Awegechew Teshome ${ }^{1}$ \\ and John T Arnason*1
}

Address: ${ }^{1}$ Department of Biology, University of Ottawa, Ottawa, Canada, ${ }^{2}$ USC Canada-East Timor, Dili, East Timor and ${ }^{3}$ Northern Australian Quarantine Strategy, Darwin, Australia

Email: Sean WM Collins - seancollins99@hotmail.com; Xisto Martins - xistomartins@yahoo.com; Andrew Mitchell - Andrew.Mitchell@aquis.gov.au; Awegechew Teshome - ateshome@usc-canada.org;

John T Arnason* - jarnason@science.uottawa.ca

* Corresponding author

Published: 22 January 2007

Journal of Ethnobiology and Ethnomedicine 2007, 3:5 doi:10.1186/1746-4269-3-5

This article is available from: http://www.ethnobiomed.com/content/3///5

(c) 2007 Collins et al; licensee BioMed Central Ltd.

This is an Open Access article distributed under the terms of the Creative Commons Attribution License (http://creativecommons.org/licenses/by/2.0), which permits unrestricted use, distribution, and reproduction in any medium, provided the original work is properly cited.

\begin{abstract}
Background: An ethnobotanical study of medicinal and poisonous plants used by the East Timor resistance was undertaken in the Lautem District of East Timor to study medicinal plant use in the region. Interviews were conducted with a single key consultant from the resistance army who belonged to the Fataluku culture. This study is of importance as a historical document and because no previous medicinal ethnobotanical studies on this region exist.
\end{abstract}

Methods: A rapid ethnobotanical survey of medicinal and poisonous plants was conducted through the proposed Conis Santana National Park in the Lautem district of East Timor. Medicinal and poisonous plants were identified by a Consultant and data was collected by the authors using classical descriptive ethnobotanical techniques (i.e. no quantitative measures) through an unstructured open ended interview.

Results: During the survey 40 medicinal and poisonous plants were identified by the Consultant and collected by the authors. Defining characteristics of the Consultant's knowledge include a high frequency use of trees, heavily forested habitats, leaves, decoctions and drinks for a range of conditions relevant to a resistance army.

Conclusion: Despite limitations of the study, important contributions of this study include preservation of a part of the cultural history of the resistance movement and traditional botanical knowledge of the Fataluku. Furthermore, initial findings may indicate that traditional botanical knowledge is unique amongst different East Timorese cultures in terms of plant selection.

\section{Background}

In May 2002, East Timor emerged as the newest nation in the world after a long and brutal Indonesian occupation which was responsible for the loss of approximately 100 , 000 to 200, 000 East Timorese lives [1]. Throughout the
Indonesian occupation, the East Timorese resistance, then known as Forças Armadas da Libertação Nacional de Timor Leste (FALANTIL), led an armed struggle against the Indonesian army. During the early years of the occupation, FALANTIL had control of a significant portion of 
the country but was eventually pushed east into the more remote jungle regions of the Lautem District. A long guerrilla conflict was fought in the forests of Lautem where small groups of FALANTIL forces evaded Indonesian troops for nearly 20 years in some cases.

It was essential during the resistance for all FALANTIL soldiers and supporters to ensure a complete working knowledge of useful forest plants to provide food and traditional medicines. The objective of this paper is to document the historical use of medicinal and poisonous plants by the FALANTIL during the resistance. The information was provided by an elder of the Fataluku people who was responsible for traditional medicine in the East Timorese resistance during the Indonesian occupation.

This research was conducted in the proposed Conis Santana National Park which is located along the south coast of the Lautem District of East Timor. The proposed park is the largest continuous forest block in East Timor and is therefore of critical importance to conservation. East Timor is primarily monsoon forest and savanna although the study area also includes small pockets of evergreen rainforest, semi-evergreen rainforest and moist deciduous forests $[2,3]$.

While this area does represent the largest continuous forest block in East Timor, the area has been disturbed in some places by illegal logging and swidden agriculture [4]. The region is a mosaic of primary and secondary forests and small patches of cleared land. One of the most striking features of the region is the extensive karst topography and the rugged Paichau, meaning 'Pig Head' in the indigenous language Fataluku, Mountains that follow the long axis of the island. Furthermore, the area is also remarkable for the extensive wetlands around the community of Mehara [4]. This wetland region is noteworthy for its extensive swamps and Lake Ira Laluro, East Timor's largest lake.

In 2000, the United Nations Transitional Authority in East Timor (UNTAET) implemented Regulation 2000/19, which declared 15 sites as 'Protected Natural Areas' (PNA) as the first step toward environmental protection in East Timor [5]. Such regulations had not been developed by the occupying Indonesian Government and were therefore a priority. Several PNA were established along the southern coast of Lautem District between Lore, Tutuala and Jaco Island which provided the platform for seeking national park status for the region [5]. In September 2003, the Ministry of Agriculture, Forestry and Fisheries of East Timor in collaboration with New South Wales Parks and Wildlife Service and Bird Life International of Australia, submitted a proposal to protect a large area of continuous forest that includes Jaco Island and a swath of land between Lake Ira Laluro and Tutuala, and the mentioned PNA [6]. Several communities are within the proposed protected area's borders and include Tutuala, Mehara and Maupitine. Full national park status is now being sought for the area by the East Timorese Ministry for Agriculture, Forestry and Fisheries with assistance from the New South Wales Parks and Wildlife Service and Bird Life International, with Conis Santana National Park being the proposed name.

Extensive research has been undertaken to document traditional use of medicinal plants throughout the Malay Archipelago [7-11]. However, due to the political instability of East Timor over the last three decades, there has been little biological research of any kind in the country. While preliminary botanical inventories [4] and bird surveys [12] have been completed in the study area, literature concerning the use of medicinal and poisonous plants in the region is absent.

The recent trend in ethnobotany has been a shift from descriptive accounts of plant use by indigenous people to hypothesis testing. This was made possible through the development of consensus indices such as those created by Phillips $[13,14]$ and Trotter and Logan [15]. A limitation of the present report is that consensus indices and hypothesis testing were not possible as only one traditional medicine expert from the resistance army was made available by local authorities. While this report does not utilize quantitative methods, it is a relevant contribution to ethnobotanical literature because the research 1) is undertaken in a biodiversity hotspot relative to other habitats in East Timor, 2) describes medicinal plant use in a conflict situation and 3 ) aids in the preservation of the unstudied traditional botanical knowledge of East Timor where local conditions continue to make such studies challenging.

\section{Methods \\ General methods}

The study consisted of a field trip through the proposed Conis Santana National Park from March 18 - 26, 2004. Former FALANTIL soldiers were hired as route finders through the forest, as specified trails were non-existent. The Consultant for the study was selected by the Chief of a nearby village on the basis that he was the most knowledgeable member of the community concerning the use of medicinal and poisonous plants. During unstructured interviews, medicinal and poisonous plants were identified by the Consultant and collected by the authors. Local name, plant part used, method of preparation and specific uses were all provided by the Consultant and recorded by the authors. The medical conditions treated by the medicinal plants were categorized by the authors according to the method developed by Cook [16]. 


\section{Voucher specimens}

Voucher specimens of all mentioned plants were collected by the authors in triplicate and stored in 70\% alcohol and later dried. One set of vouchers is stored at each of the Universidade Nacional Timor Lorosae'e, Dili, East Timor; the Northern Territory Herbarium, Darwin, Australia; and the University of Ottawa, Ottawa, Canada. Identifications were made by Andrew Mitchell of Northern Australian Quarantine Strategy. Taxonomic identifications were difficult to determine as most samples were sterile.

\section{The consultant}

The Consultant was between 60 and 70 years of age and spoke both Bahassa Indonesian and the local language Fataluku. His spirituality was animist. As is the case with most East Timorese living in rural areas, he was a peasant farmer whose most important crops were corn and cassava. It is important to note that both corn and cassava both originate from the New World. This demonstrates a global exchange of ethnobotanical knowledge which impacts all cultures and findings of ethnobotanical investigation including the findings of this research. While the Consultant's home village was a remote community in the area of the proposed park, his community had been relocated by the Indonesian Government to a roadside location, during the 1970 s.

As a youth, the Consultant had been trained by a Fataluku elder from the Consultant's home village in medicinal and traditional plant use. Although the training was informal, the Consultant became an apprentice of the elder and was required to prepare a written account of the knowledge in Bahassa Indonesian. At the present time, the Consultant's teacher lives by himself in the community's traditional territory within the proposed park, residing in limestone caves and surviving by hunting and gathering in the forest and swidden agriculture.

\section{Ethical approval}

Prior to undertaking field activities, the District Administrator for Lautem District was consulted and asked for permission to work in the research area. Furthermore, a meeting was held to explain the objectives of the research and receive consent from the village Chief and elders. Ethical approval was granted by the University of Ottawa Ethics Committee with the understanding that the Consultant's identity would be kept confidential. The Ministry of Agriculture, Forestry and Fisheries of East Timor was consulted prior to conducting research, however, collecting permits were not issued as regulations have yet to be developed. Furthermore, the Consultant explicitly stated that he felt it important to publish his knowledge of medicinal plants to a broad audience.

\section{Results and discussion}

In total 40 plant species were identified by the Consultant and collected by the authors of which 35 were used to treat human ailments, 2 were used for veterinary purposes and 3 were poisons (Table 1). 20 of the medicinal plants were identified to species, 13 to genus and 3 to family and 4 were not identified to any level. Identifications were difficult as many plant vouchers lacked flowers or fruit. The most commonly mentioned families were the Fabaceae ( 4 species) and the Euphorbiaceae (3 species). When compared to other ethnobotanical studies, the number of medicinal plants mentioned is exceptionally high. For example, Giday et al. [17] described the medicinal use of 33 species used by 17 key informants of the Zay people of Ethiopia. Long and Li [18] documented the use of medicinal plants by the Red headed Yao people of China where they listed only 66 medicinal plant species used by healers, herbalist and elders in seven districts.

The most commonly mentioned usage categories were Infections/Infestations, Injuries and Muscular/Skeletal System Disorders (Table 2). The high number of mentions of both Injuries and Muscular/Skeletal System Disorders is a reflection of the Consultant's accumulated experience treating FALANTIL soldiers and East Timorese civilians wounded during altercations with the Indonesian army and militias. While on the field trip, we met a family who had homesteaded within the park. During the Indonesian occupation, the father was returning home along a jungle path from the district capital, Los Palos. The man was ambushed by a group of Indonesian soldiers patrolling the area and was left for dead after a vicious machete attack. Fortunately, the man made it back to his homestead where his wife was able to treat him using traditional medicine. Incidents such as this commonly resulted in serious life threatening wounds such as severe blood loss and fractures. Treatments used include those which act as coagulants and remedies to mend bone fractures. An unidentified vine, used to treat wounds that are bleeding heavily was cut into a foot long section and sap was extruded onto the wound by blowing into one of the cut ends. Poultices were made from the fruit of coconut (Cocos nucifera) and from the bark of Schefflera sp. B (Figure 1) and applied to broken bones before being secured firmly in place with cloth.

Of the Infections/Infestations usage category, malaria, hepatitis and pink eye were the most commonly mentioned specific uses. The Consultant noted that malaria is an easily curable disease whose treatment is very common knowledge in East Timor. Papaya (Carica papaya) leaves or the leaves of Momordica sp. were boiled in water and the decoction drank or used as a shower and drank in the respective remedies. The small intestines of the cuscus (Phalanger sp.), a small nocturnal marsupial, were also 
Table I: Family, botanical name, Fataluku name and specific uses of $\mathbf{4 0}$ medicinal and poisonous plant species collected in the proposed Conis Santana National Park.

\begin{tabular}{|c|c|c|c|c|}
\hline Family & Botanical Name & Voucher & Fataluku Name & Specific Uses \\
\hline Anacardiaceae & Mangifera indica L. & UO 19564 & Payahi & wounds \\
\hline \multirow[t]{2}{*}{ Apocynaceae } & Alstonia species B R.Br. & UO 19575 & Wiahara & diarrhea \\
\hline & Cerbera manghas L. & UO 19591 & Amibya & lactation stimulant \\
\hline Araceae & Monstera species Adans. & UO 19570 & Nae nae rasa & wounds \\
\hline \multirow[t]{2}{*}{ Araliaceae } & Schefflera species B J.R.Forst. \& G.Forst. & UO 19590 & Latuporo & veterinary medicine \\
\hline & Schefflera species C J.R.Forst. \& G.Forst. & UO 19592 & Tufutu & fractures \\
\hline Arecaceae & Cocos nucifera $\mathrm{L}$. & UO 19565 & Vata mimiraka & fractures \\
\hline Caricaceae & Carica papaya L. & UO 19607 & Muu & malaria \\
\hline Crassulaceae & Bryophyllum species Salisb. & UO 19596 & Pipivalikerekere & ear infections \\
\hline Cucurbitaceae & Momordica species L. & UO 19604 & Kapinu & malaria \\
\hline Cycadaceae & Cycas species L. & UO 19573 & Beku & wounds \\
\hline Dioscoreaceae & Dioscorea bulbifera L. & UO 19579 & Churailahoo & wild game poison \\
\hline \multirow[t]{3}{*}{ Euphorbiaceae } & Aleurites moluccana (L.) Willd. & UO 19568 & Pokuru & post partum bleeding, internal bleeding \\
\hline & Euphorbia atoto G.Forst. & UO 19599 & Foy hasa reku reku & low quality breast milk \\
\hline & Jatropha curcas L. & UO 19598 & Mutu mutu mimi raka & urinary tract infection \\
\hline \multirow[t]{4}{*}{ Fabaceae } & Albizia lebbeck (L.) Benth. & UO 19585 & Iparakuliku & pink eye \\
\hline & Derris species B Lour. & UO 19603 & Cha & fish poison \\
\hline & Pterocarpus indicus Willd. & UO 1957। & Makari & mouth sores \\
\hline & Tamarindus indica $\mathrm{L}$. & UO 19589 & Kaylemu & sore joints \\
\hline Lamiaceae & Leucas species $\mathbf{R} . \mathbf{B r}$. & UO 19587 & Muka muka & sores, eye trauma \\
\hline Lecythidaceae & Barringtonia asiatica (L.) Kurz & UO 19594 & Coru & inflammation \\
\hline Leeaceae & Leea indica Merr. & UO 19562 & Motiir & diarrhea \\
\hline Loranthaceae & Amyema species B Tiegh002E & UO 19601 & Laki soru aku & Urinary tract infections \\
\hline Malvaceae & Hibiscus species $L$. & UO 19563 & Varu & Wounds \\
\hline \multirow[t]{2}{*}{ Meliaceae } & Unknown & UO 19580 & Pepuru & veterinary medicine \\
\hline & Azadirachta indica A. Juss. & UO 19582 & Erua & sore joints \\
\hline Menispermaceae & Tinospora smilacina Benth. & UO 19602 & Shururu & lice infestation, snake bite \\
\hline Myristicaceae & Unknown & UO 19583 & Paunete & fish poison \\
\hline Piperaceae & Piper species L. & UO 19584 & Tarukukurisa & itching \\
\hline \multirow[t]{2}{*}{ Poaceae } & Unknown & UO 19574 & Severoo & weight loss \\
\hline & Imperata cylindrica (L.) P.Beauv. & UO 19576 & Beerasa & helminth worm infection \\
\hline Polypodiaceae & Drynaria quercifolia (L.) J. Sm. & UO 19578 & Sa-pu & throat infections \\
\hline \multirow[t]{2}{*}{ Rubiaceae } & Pavetta species L. & UO 1956। & Lalamoo & tuberculosis \\
\hline & Nauclea orientalis (L.) L. & UO 19566 & Savele & pink eye, post partum bleeding, internal bleeding \\
\hline Rutaceae & Citrus hystrix DC. & UO 19595 & Ami churuku & hepatitis, inflammation \\
\hline Verbenaceae & Gmelina philippensis Lam. & UO 19588 & Kapuasamaru & hepatitis \\
\hline unknown & Unknown & UO 19577 & Ai-anu & muscle relaxant \\
\hline unknown & Unknown & UO 19572 & Luluparoo & wounds \\
\hline unknown & Unknown & UO 19600 & Pia pia & dysentery \\
\hline unknown & Unknown & UO 19567 & Tua tua hikari & cough \\
\hline
\end{tabular}

used to treat malaria. While collecting medicinal plants, the two FALANTIL guides constantly scanned dead standing trees for signs of the cuscus' nest. When a nest was spotted, one of the men climbed the large dead standing trees unaided and removed the cuscus by the tail. The primary reason for hunting the cuscus was for the meat, however, the small intestines can be boiled or roasted and eaten to treat malaria. It was believed that the small intestine has curative properties because the cuscus feeds heavily on Derris sp. and Tinospora smilacina. T. smilacina is used traditionally in Australia to treat infections and inflammatory conditions and was found to have significant anti-inflammatory activity by Li et al. $[19,20]$. Furthermore, Derris spp. are traditionally used as fish poisons throughout South East Asia and have highly active compounds known as rotenones [21].
The two veterinary medicines, Schefflera sp.A and the unidentified Meliaceae species were respectively used to treat goats and dogs with mange, and also as a general tonic cure for sick livestock. The root of Dioscorea bulbifera was either cooked or used raw to poison wild animals such as pigs and dogs. The root was combined with food such as rice or cassava and then left on game trails. Once dead, the meat of the game animal is edible, however, it was mentioned that the toxins accumulate in the organs making them inedible. In the case of the unidentified Myristicaceae and Derris sp. the root and bark or stem only were used in the respective preparations. The macerated plant material was added to small confined bodies of water such as tidal pools or creek pools in the dry season. These preparations are effective poisons for shrimp and fish such as eels. 
Table 2: Frequency of usage category mentions for medicinal and poisonous plant species collected in the proposed Conis Santana National Park.

\begin{tabular}{lc}
\hline Usage Category & Number of Mentions \\
\hline Infections/Infestations & II \\
Injuries & 7 \\
Muscular-Skeletal System Disorders & 5 \\
Poisons & 3 \\
Digestive System Disorders & 3 \\
Preganancy/Birth/Puerperium Disorders/Effects & 3 \\
Skin/Subcutaneous Cellular Tissue Disorders & 3 \\
Genitourinary System Disorders & 2 \\
Inflammations & 2 \\
Veterinary Medicines & 2 \\
Culture Bound Syndromes & $\mathrm{I}$ \\
Nutritional Disorders & $\mathrm{I}$ \\
Poisoning Disorders & $\mathrm{I}$ \\
Respiratory System Disorders & $\mathrm{I}$ \\
\hline
\end{tabular}

The plants were analyzed according to frequency of use with respect to plant habitat and growth form, plant part used, method of remedy preparation and route of administration. However, it is important to note that number of mentions for plant part used, method of preparation and route of administration do not equal the total number of species as there were often multiple mentions in these categories per species. Of the 40 useful plant species, 21 were trees while vines and herbs were both used in over $10 \%$ of the mentions (Figure 2). Heavily forested areas were mentioned often (35 of 40 mentions) while cultivated fields, beaches and dry steam beds accounted respectively for 2 , 2 and 1 of 40 mentions respectively. Leaves (17 of 47) and bark (12 of 47) were the most commonly used plant part (Figure 3). When the bark is used, the outer tissue is removed and the inner bark is collected and prepared. The bark is commonly taken from the tree in long strips and then dried in the sun thereby preserving the remedy for future use.

Decoctions were used for 18 of the 44 preparation mentions (Figure 4). Macerating (10 of 44) the plant material with a stone or using a traditional mill was also common. No preparation was required for 8 of the uses which were usually sap remedies administered topically or treatments that were chewed or eaten. The most common route of administration was a drink which was used for 13 of the 49 administration mentions (Figure 5). Other oral routes include eating ( 4 of 49 ) or chewing ( 2 of 49 ). The most common external administration was showering (11 of 49 ) but topical routes (10 of 49) and poultices ( 6 of 49) were also used. The only example of combining medicinal plants in a remedy was that of adding the bark from Aleurites moluccana to that of Nauclea orientalis to treat internal and post partum bleeding.

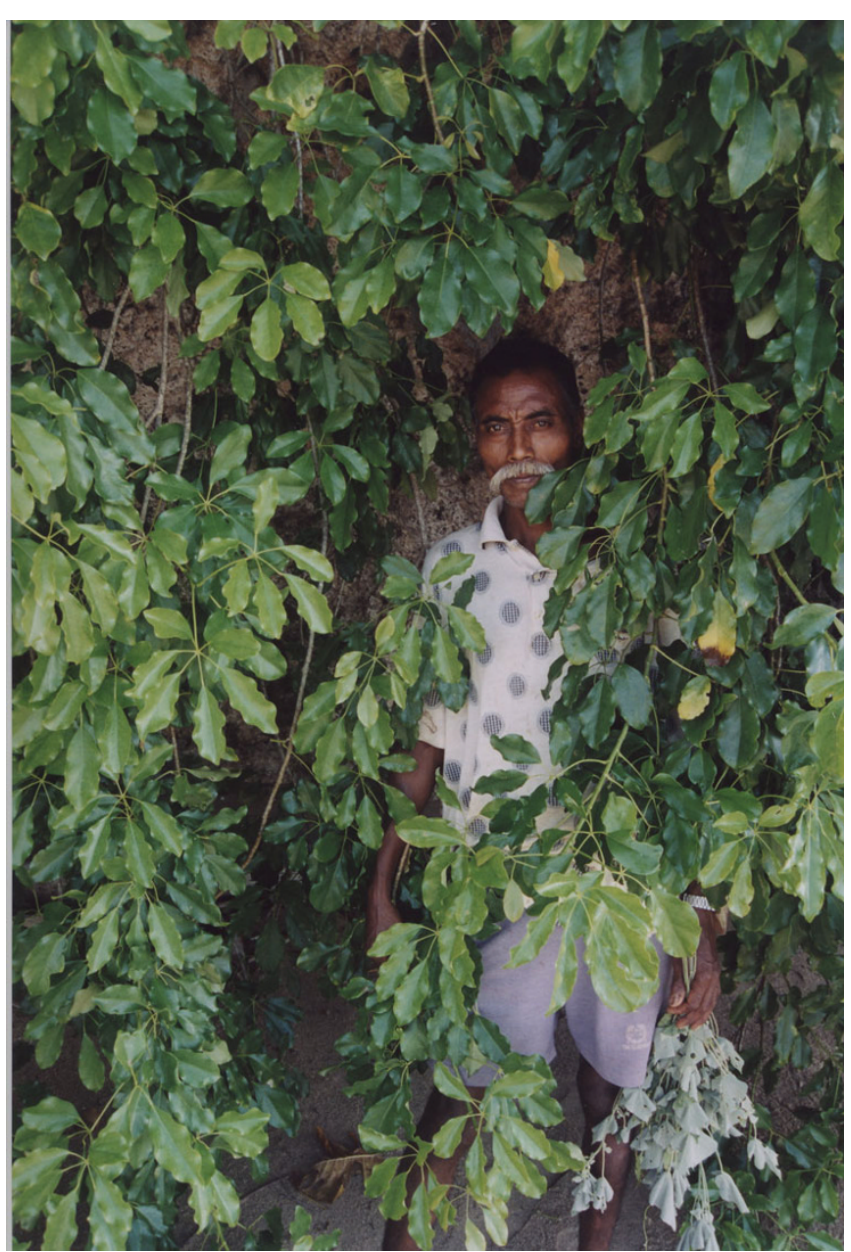

Figure I

A poultice made from the bark of Schefflera species B is used to treat bone fractures.

Several of the plants mentioned by the Consultant have been used by other cultures as medicinal plants and have also been investigated for pharmacological activity. For example, Pterocarpus indicus (Figure 6) is used to treat "sores and minor wounds" in an unspecified South-East Asian country as cited by Khan and Omoloso [22] and was found to have significant antibacterial activity [22]. Dioscorea bulbifera is a traditional Chinese remedy for sore throat and also for tuberculosis as mentioned by Gao et al. [23] who found that extracts had anti-tumor effects [23].

The plant species identified by the Consultant are markedly different from the medicinal flora of the Idate and Laklei East Timorese cultures documented in previous ethnobotanical research. Of the 40 plants collected, 32 were different species from the medicinal flora of the Laklei or the Idate people of East Timor consisting of 86 plant species [24]. The Consultant's differing pharmacopeia is most likely due to differing site conditions and perhaps unique 


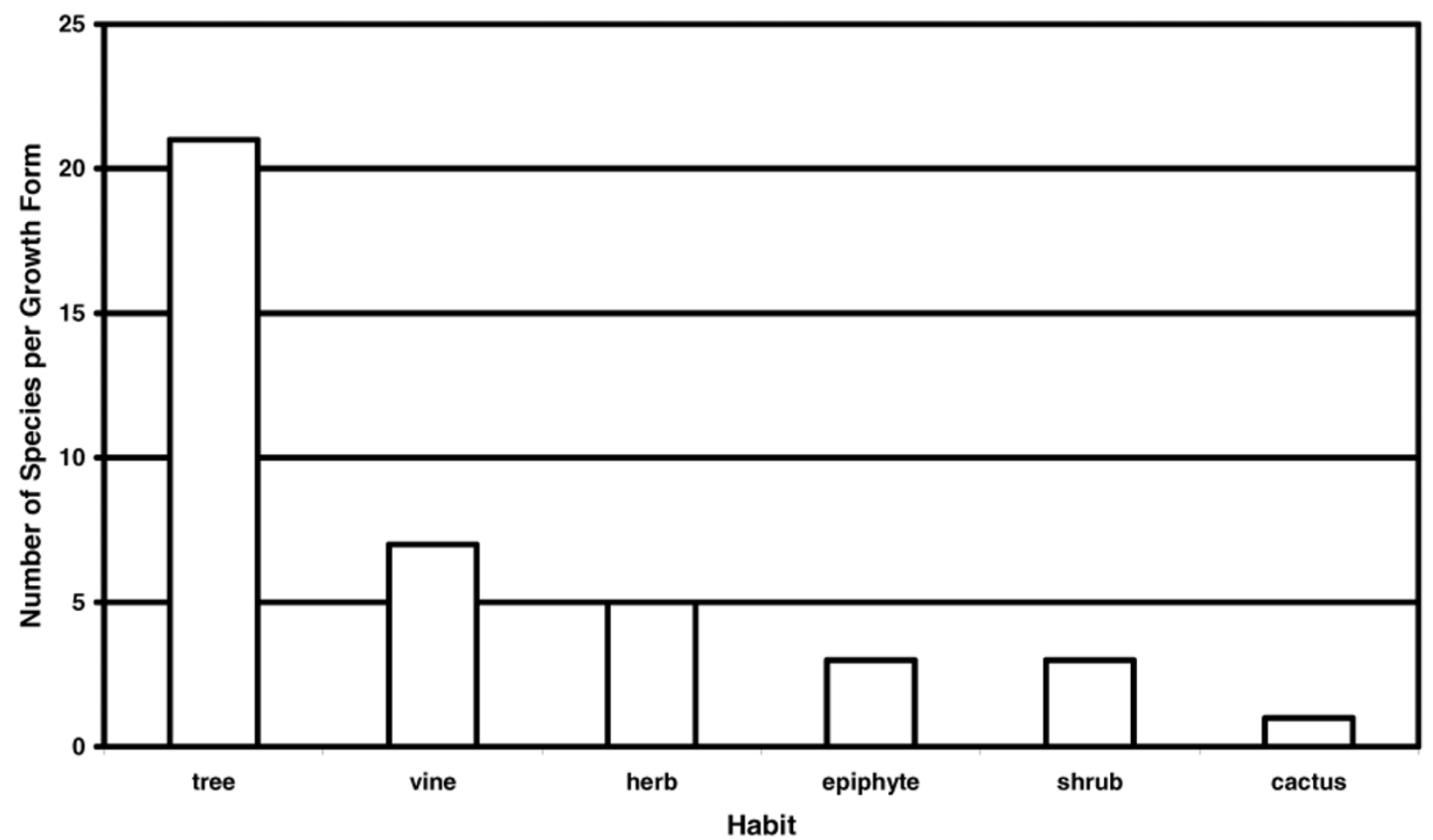

Figure 2

Number of species per growth form for 40 medicinal and poisonous plant species collected in the proposed Conis Santana National Park.

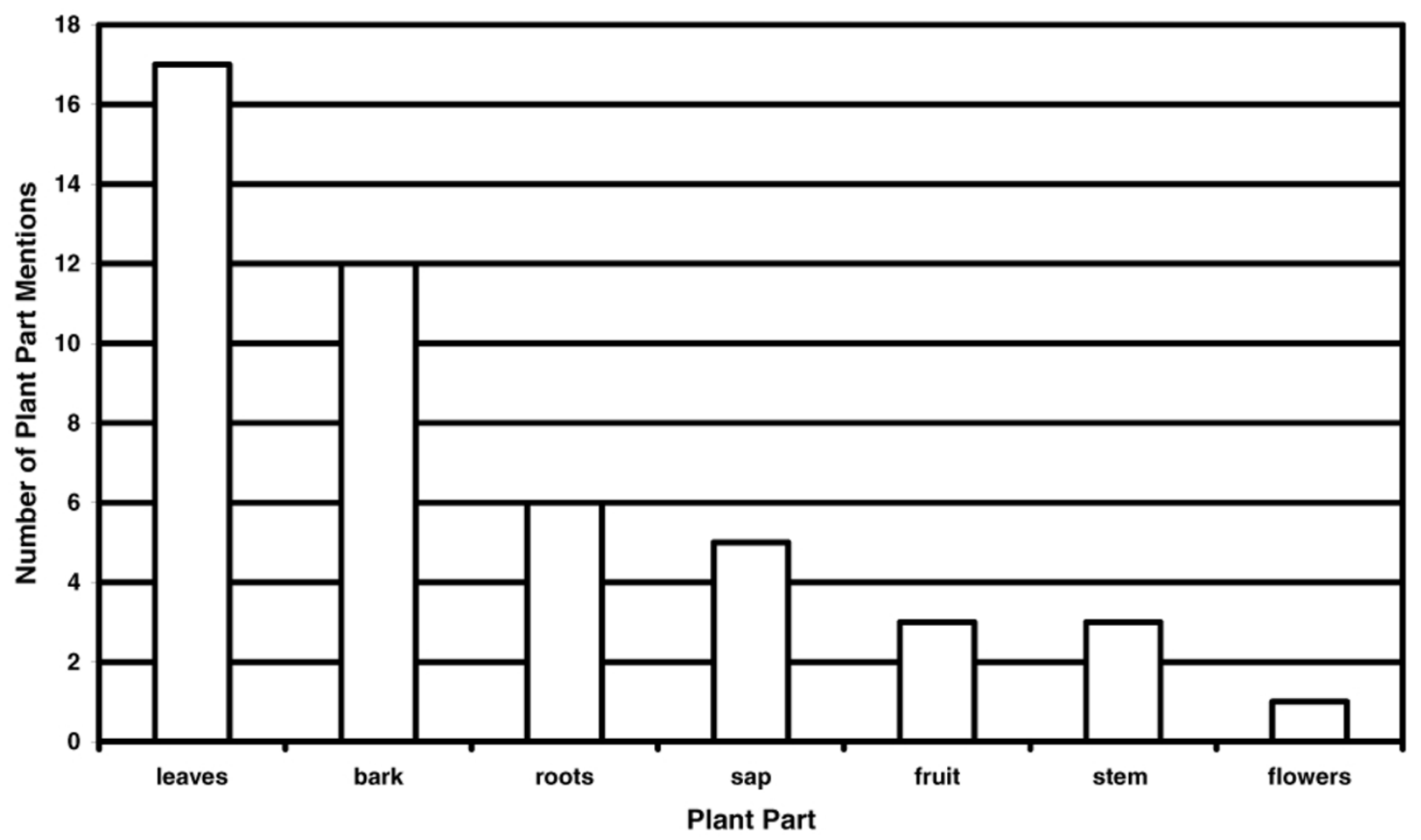

Figure 3

Number of plant part mentions for 40 medicinal and poisonous plant species collected in the proposed Conis Santana National Park. 


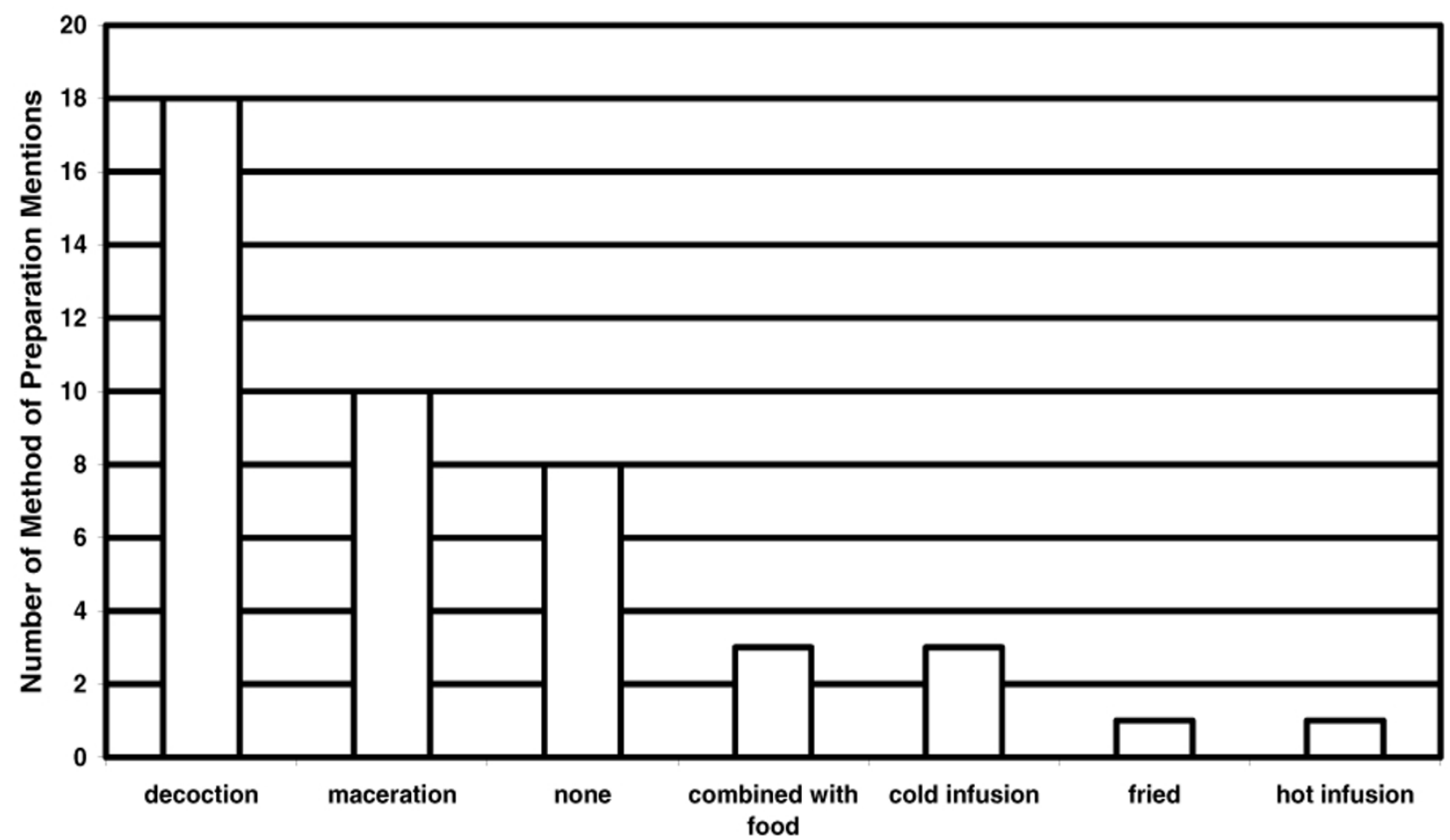

Method of Preparation

Figure 4

Number of method of preparation mentions for 40 medicinal and poisonous plant species collected in the proposed Conis Santana National Park.

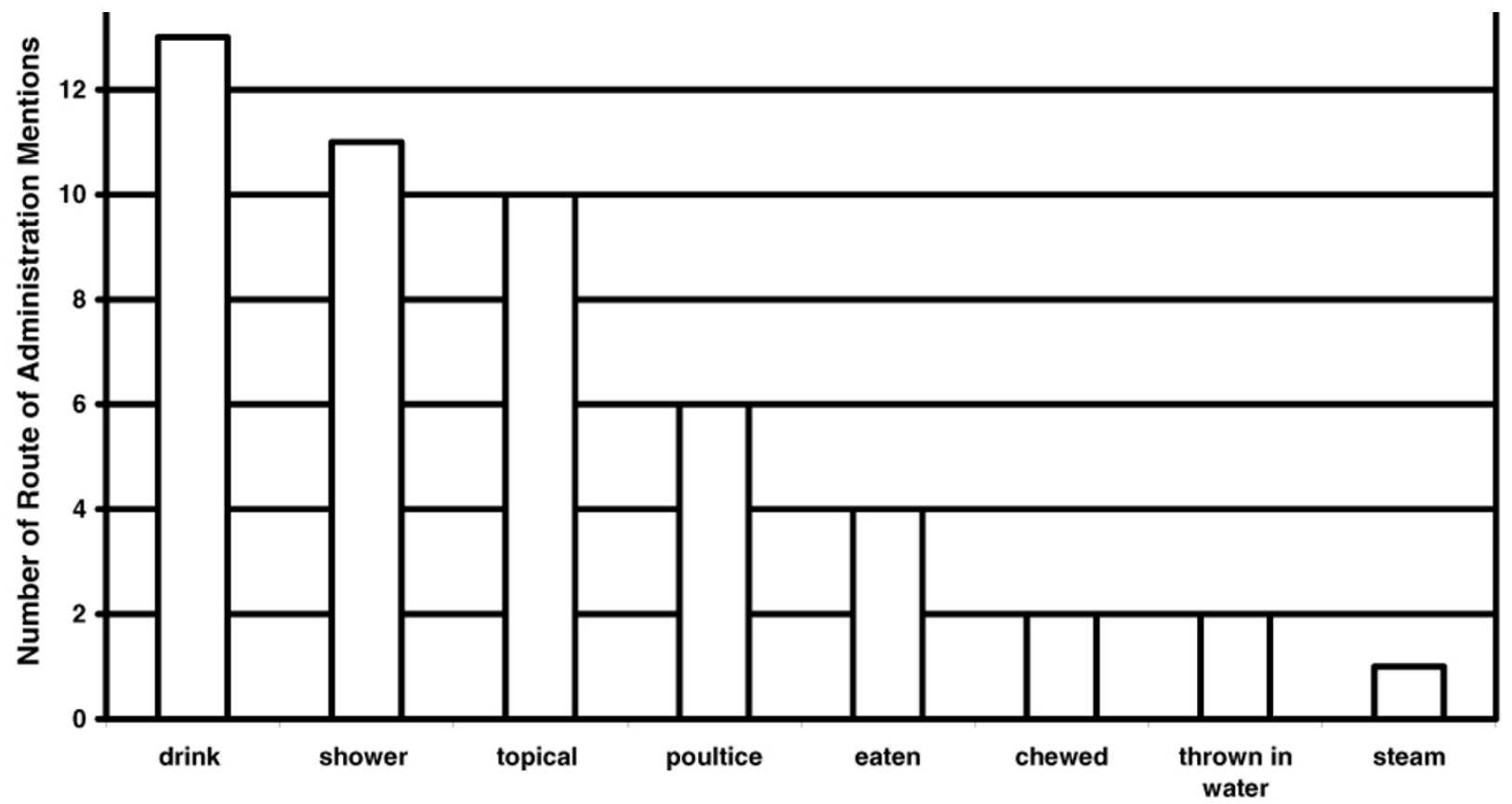

Route of Administration

Figure 5

Number of route of administration mentions for $\mathbf{4 0}$ medicinal and poisonous plant species collected in the proposed Conis Santana National Park. 


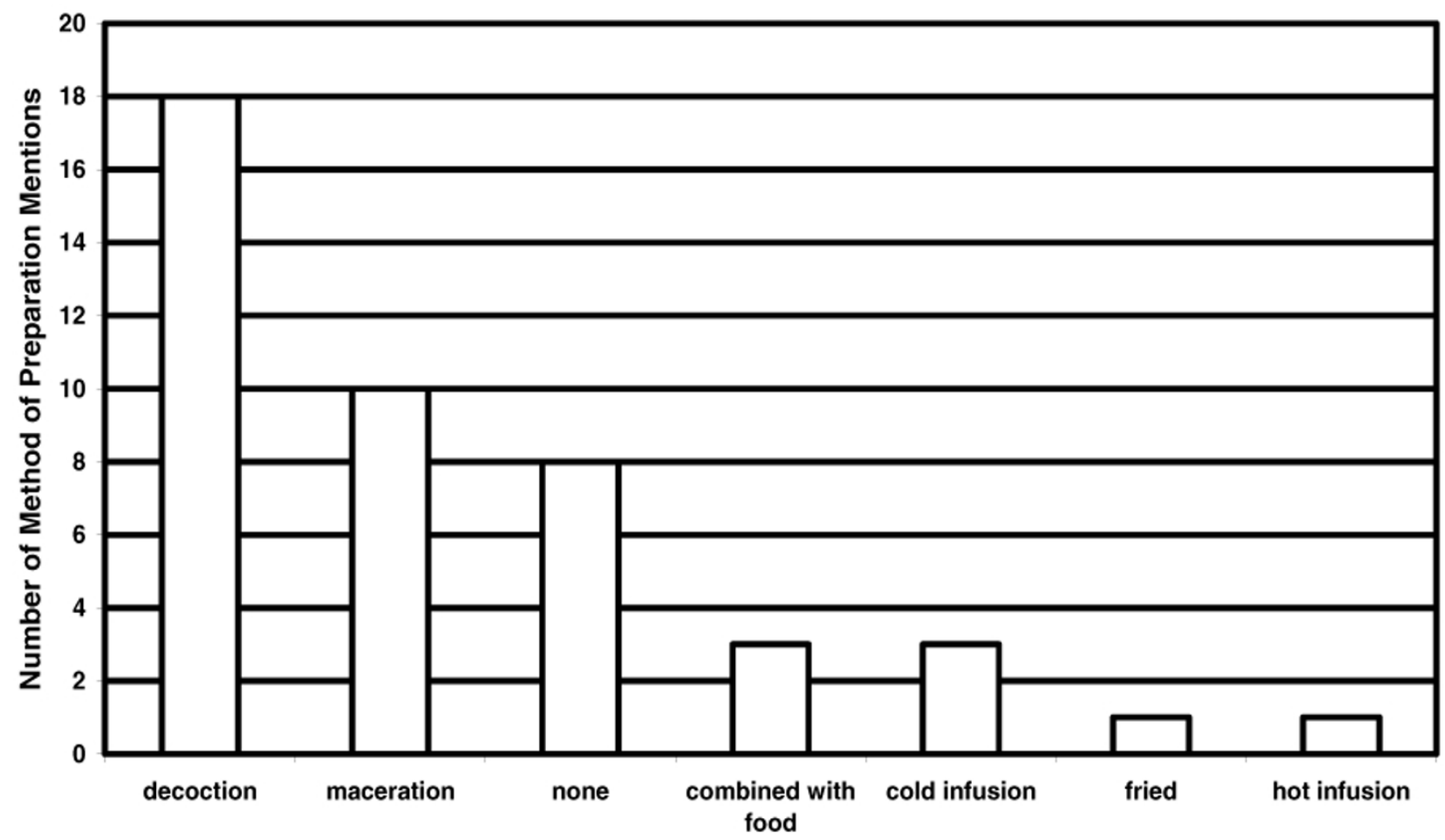

Method of Preparation

\section{Figure 4}

Number of method of preparation mentions for 40 medicinal and poisonous plant species collected in the proposed Conis Santana National Park.

cultures. Conditions at Conis Santana National Park include 1) high annual rainfall, 2) low human presence and therefore human disturbance, 3 ) and large patches of primary and extensive stands of secondary forest exist compared to the heavily degraded landscape that dominates much of East Timor [25]. All of these defining characteristics contribute to significant differences in the flora of Conis Santana National Park and therefore the medicinal plants collected. Furthermore, different cultural groups may have significantly different medicinal plant traditions where the plant species used will be unique as noted by Collins [24]. However, because only one consultant was interviewed in this study it is unclear whether the Consultant's knowledge represents his own specilalized knowledge or the Fataluku medicinal plant tradition as a whole. Furthermore, several of the plants identified by the Consultant are introduced species therefore the suite of plants identified may not represent an ancient Fataluku tradition but a more contemporary body of knowledge subject to a more modern ethnobotanical condition; namely the greater exchange of ethnobotanical knowledge on a global scale. While the medicinal plant species and habitat of collection differ from other areas in East Timor, several similarities exist. For example, the most frequently used plant part (leaves and bark), prepa- ration method (decoctions, macerations and no preparation), habitat (forest) and route of administration (drink) were the same for the Idate, Laklei and Fataluku people [24]. These similarities may indicate unifying characteristics of the East Timorese medicinal plant tradition in general.

The Consultant's knowledge of medicinal and poisonous plants may in part be a result of the degree to which he had to rely on the local flora during the recent political unrest. It was common for entire villages to flee to the mountains to seek refuge from the brutality that began when the Indonesian army invaded in 1975 and continued through to the violence that followed the referendum in August of 1999. Many East Timorese can recount stories of having to survive in the forest under harsh conditions, where they were forced to live on papaya leaves for months at a time as it was too dangerous to return to roadside communities where Indonesian forces had control. Traditional medicine was relied upon heavily to treat ailments since seeking medical attention in city centres such as Dili and Baucau was not an option as these were the strongholds of the Indonesian occupation force. The reliance on the natural environment by FALANTIL soldiers was even greater as they were actively pursued by Indone- 


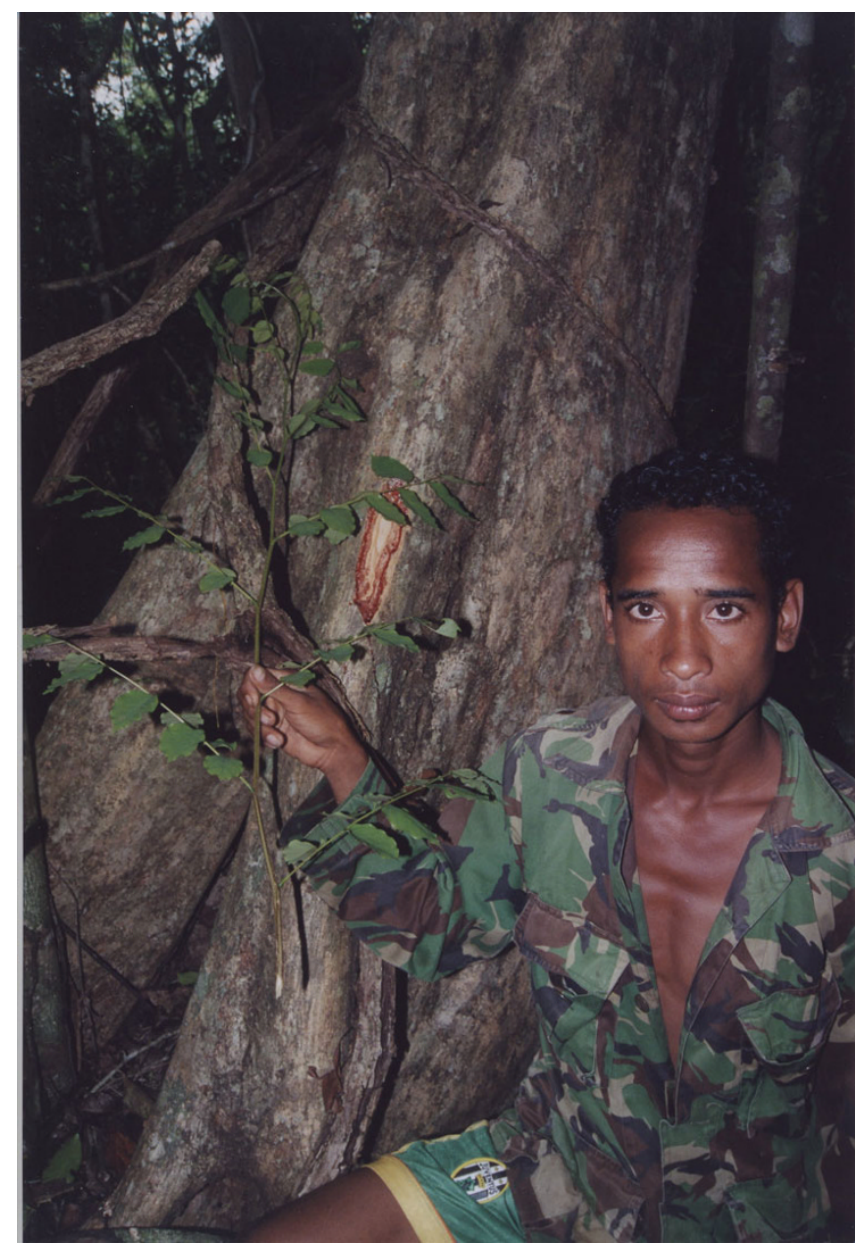

Figure 6

The sap of Pterocarpus indicus is used topically to treat mouth sores.

sian forces in the forest. They could not carry adequate equipment, and as one former FALANTIL soldier stated: "During an ambush, you only had time to grab your gun and flee".

Many East Timorese have a working knowledge of useful plants, however the knowledge of the Consultant is exceptional for two key reasons. First, he had a mentor who instructed him on useful plants and their various preparations. Secondly, he grew up and later lived in close proximity to the stronghold of the East Timorese resistance army, FALANTIL. The Consultant was not a FALANTIL soldier himself, but provided critical support to the resistance by caring for sick soldiers and passing on his knowledge of medicinal plants.
While making the plant collection and conducting interviews, it was apparent that the two former FALANTIL soldiers also knew some remedies by the fact that they were able to clarify certain details. However, younger members of the expedition clearly had little or no knowledge of the plants. This presents a serious obstacle to maintaining traditional medicinal plant knowledge. Fostering interest in medicinal plants among younger members of the community is made difficult by the hospital in the district capital of Los Palos. The pharmaceutical drugs and western treatments offered by the hospital are rendering knowledge of local medicinal plants and their uses obsolete according to the youth. The loss of traditional botanical knowledge is a global phenomenon $[26,27]$ which erodes local and our global cultural heritage.

\section{Conclusion}

The study is a preliminary investigation of the use of medicinal and poisonous plants in a region of the world where, until now, such investigation has been absent. While significant limitations of this study exist, namely a sample size of one and incomplete identification of voucher specimens, initial findings are important as they provide baseline data on traditional botanical knowledge in the area which aids in preserving this type of information for future generations of East Timorese and comparison to future more in depth ethnobotanical study in the area. Although the one key Consultant's knowledge does not describe Fataluku traditional botanical knowledge in its' entirety, the medicinal and poisonous plants used by the Consultant are dramatically different than consultants from other East Timorese cultures, namely the Idate and Laklei people. In fact only 8 of the 40 plants identified in this study are used by either the Idate or Laklei people.

\section{Competing interests}

The authors declare that they have no competing interests.

\section{Authors' contributions}

SC carried out field work, collected and analysed the primary data and drafted the manuscript. XM coordinated field work and logistics and made revisions to the manuscript. AM identified plant vouchers. AT coordinated field work between collaborators in East Timor and Canada and also commented on the manuscript. JTA coordinated field work and made revisions to the manuscript.

\section{Acknowledgements}

We would like to express our gratitude to the healer involved in this project for working with us and providing us with insight into the healing tradition of the Fataluku people. We are also grateful to the former FALANTIL soldiers and young men who helped on this expedition as trail guides and porters. Finally, we would like to thank USC Canada for providing funding for this research. Viva Timor Loro'sae! 


\section{References}

I. Cotton J: Against the grain: the East Timor intervention. Survival 200I, 43: I27-I42.

2. Monk KA, Fretes YD, Reksodiharjo-Lilley G: The Ecology of Nusa Tenggara and Maluku. Vol. V. The Ecology of Indonesia Series Singapore: Periplus Editions (HK) Ltd; 1997.

3. Whitmore TC: Tropical rain forests of the far east Oxford University Press, Great Britain; 1975.

4. Whistler A: Ecological survey and preliminary botanical inventory of the Tutuala beach and Jaco Island Protected Natural Areas, East Timor. A United Nations Transitional Administration in East Timor (UNTAET) paper $200 \mathrm{I}$.

5. UNTAET: Regulation $2000 / 19$ on protected places. United Nations Transitional Administration in East Timor. 2000.

6. Ministry of Agriculture, Forestry and Fisheries, Republica Democratica de Timor-Leste, New South Wales National Parks and Wildlife Service and Bird Life International: Proposal to establish a protected area network in Timor-Leste. 2003.

7. Elliott S, Brimacombe J: The medicinal plants of Gunung Leuser National Park, Indonesia. Journal of Ethnopharmacology 1987, 19:285-317.

8. Grosvenor PW, Gothard PK, McWilliam NC, Supriono A, Gray DO: Medicinal plants from Riau Province, Sumatra, Indonesia. Part I: uses. Journal of Ethnopharmacology 1995, 45:75-95.

9. Hirschhorn $\mathrm{HH}$ : Botanical remedies of the former Dutch East Indies (Indonesia). Part I: eumycetes, pteridophyta, gymnospermae, angiospermae (monocotyledones only). Journal of Ethnopharmacology 1983, 7:123-156.

10. Holdsworth D, Wamoi B: Medicinal plants of the Admiralty Islands, Papua New Guinea Part I. International Journal of Crude Drug Research 1982, 20:169-181.

II. Leaman DJ, Arnason JT, Yusuf R, Sangat-Roemantyo H, Soedjito H, Angerhofer CK, Pezzuto JM: Malaria remedies of the Kenyah of the Apo Kayan, East Kalimantan, Indonesian Borneo: a quantitative assessment of local consensus as an indicator of biological efficacy. Journal of Ethnopharmacology 1995, 49: I-I6.

12. Trainor C: A preliminary list of important bird areas in East Timor - interim list of priority sites for biodiversity conservation in Asia's newest country. BirdLife International - Asia Division 2002.

13. Phillips O, Gentry AH: The useful plants of Tambopata, Peru: I. Statistical hypotheses tests with a new quantitative technique. Economic Botany 1993, 47:15-32.

14. Phillips O, Gentry AH: The useful plants of Tambopata, Peru: II. Additional hypothesis testing in quantitative ethnobotany. Economic Botany 1993, 47:33-43.

15. Trotter RT, Logan MH: Informant consensus: a new approach for identifying potentially effective medicinal plants. In Plants in indigenous medicine and diet Edited by: Etkin NL. Redgrave Publishing Company, Bedford Hill, New York; 1986:91-II2.

16. Cook FEM: Economic botany data collection standard Edited by: Prendergast HDV. Royal Botanic Gardens, Kew, United Kingdom; 1995.

17. Giday M, Asfaw Z, Elmqvist T, Woldu Z: An ethnobotanical study of medicinal plants used by the Zay people in Ethiopia. Journal of Ethnopharmacology 2003, 85:43-52.

18. Long C, Li R: Ethnobotanical studies on medicinal plants used by the Red-headed Yao people in Jinping, Yunnan Province, China. Journal of Ethnopharmacology 2004, 90:389-395.

19. Li RW, Myers SP, Leach DN, Lin GD, Leach G: A cross-cultural study: anti-inflammatory activity of Australian and Chinese plants. Journal of Ethnopharmacology 2003, 85:25-32.

20. Li RW, Leach DN, Myers SP, Leach GJ, Lin GD, Brushett DJ, Waterman PG: Anti-inflammatory activity, cytotoxicity and active compounds of Tinospora smilacina Benth. Phytotherapy Research 2004, 1 8:78-83.

21. de Padua LS, Bunyapraphatsara N, Lemmens RHMJ, (Eds): Plant Resources of South-East Asia No I2(I). Medicinal and poisonous plants I Leiden, the Netherlands: Backhuys Publishers; 1999.

22. Khan MR, Omoloso AD: Antibacterial activity of Pterocarpus indicus. Fitoterapia 2003, 74:603-605.

23. Gao H, Kuroyanagi M, Wu L, Kawahara N, Yasuno T, Nakamura $Y$ : Antitumor-promoting constituents from Dioscorea bulbifera L. in JB6 mouse epidermal cells. Biol Pharm Bull 2002, 25: $124 \mid-1243$.

24. Collins S: The Ethnobotany of East Timor. In MSc thesis University of Ottawa, Canada, Department of Biology; 2005.
25. Bouma G, Kobryn H: Assessing vegetation change in East Timor using landsat thematic mapper data. In Technical Report No. 01/02 Murdoch University, School of Environmental Science, Australia; 2002.

26. Boom B: Ethnobotany of the Chacobo Indians, Beni, Bolivia. Advances in Economic Botany 1987, 4: I-70.

27. Schultes RE: The reason for ethnobotanical conservation. In The Conservation of Medicinal Plants Edited by: Akerele O, Heywood V, Synge H. Cambridge University press, Cambridge:65-75.

Publish with Bio Med Central and every scientist can read your work free of charge

"BioMed Central will be the most significant development for disseminating the results of biomedical research in our lifetime. "

Sir Paul Nurse, Cancer Research UK

Your research papers will be:

- available free of charge to the entire biomedical community

- peer reviewed and published immediately upon acceptance

- cited in PubMed and archived on PubMed Central

- yours - you keep the copyright

Submit your manuscript here:

http://www.biomedcentral.com/info/publishing_adv.asp
BiolMedcentral 